\title{
IDENTIFIKASI JENIS KEGIATAN DAN PERUBAHAN WARNA RAMBUT PADA PEKERJA PENGOLAH JANUR IBUNG
}

\author{
Ni Made Marwati, ${ }^{1}$ Ni Ketut Rusminingsih, ${ }^{2}$ M.Choirul Hadi ${ }^{3}$ \\ 1, 2, 3 Jurusan Kesehatan Lingkungan Poltekkes Denpasar \\ marwatinimade@ymail.com
}

\begin{abstract}
Coloration janur ibung process into whitish color using hydrogen peroxide and fragrance ingredients added with salt. This research aims to identify each type of coloration activities, type of chemicals, personal protective equipment used, hair color changes in workers and to analyze the type of janur ibung coloration activities to hair color changes in workers. This study was an observational study with cross sectional approach. Samples are dyes and workers in januribung processing. The sample size are 18 workers. Sampling method using simple random sampling. Dyes sample tested in laboratory for the possible parameter contained in red dyes, for white dyes. Data of personal protective equiment and type of activities on janur ibung processing obtained by observation using questionnaire. The test results showed the dyes used containing Rhodamin $B$, Mercury, Iron and Ammonia. Type of activities in the janur ibung processing include dyeing, binding and drying in which workers do not use cap on any activities and all the workers experienced hair color changes. Janur ibung processing workers who exposured to dyes are at risk to hair color changes into red brown.
\end{abstract}

Key words: dyes, household industry, work safety

\begin{abstract}
Abstrak. Pembentukan warna putih janur ibung menggunakan Hidrogen Peroksida $\left(\mathrm{H}_{2} \mathrm{O}_{2}\right)$ dan ditambah bahan pewangi serta garam dapur. Penelitian ini bertujuan mengidentifikasi jenis kegiatan, bahan kimia dan alat pelindung diri yang dipakai, mengidentifikasi perubahan warna rambut pekerja serta menganalisis jenis kegiatan dengan perubahan warna rambut para pekerja pengolah janur ibung. Penelitian ini termasuk penelitian observasional dengan pendekatan cross sectional. Sebagai sampel penelitian adalah 18 orang pekerja pengolah janur ibung zat pewarna.yang diambil dengan teknik simple random sampling. Sampel zat pewarna diuji di laboratorium untuk parameter yang dimungkinkan terkandung pada pewarna. Hasil uji menunjukkan zat pewarna yang digunakan mengandung Rhodamin B, Merkuri, Besi dan Amonia. Jenis kegiatan pada pengolahan janur ibung yang teridentifikasi adalah pencelupan, pengikatan dan penjemuran, dimana pekerja tidak menggunakan tutup kepala pada setiap jenis kegiatannya, dan ditemukan bahwa semua pekerja mengalami perubahan warna rambut. Seluruh pekerja pengolah janur ibung yang terpapar zat pewarna berisiko mengalami perubahan warna rambut menjadi merah kecoklatan.
\end{abstract}

Kata kunci: zat pewarna, industri rumah tangga, keselamatan kerja. 


\section{Pendahuluan}

Hampir seluruh upakara keagamaan di Bali menggunakan janur. Hanya karena untuk mempermudah persiapan upakara masyarakat Hindu di Bali memilih menggunakan janur ibung. Janur Ibung warna dasarnya kecoklatan, entah dengan maksud untuk diawetkan atau hanya untuk menjadikan warna lebih putih bersih, sehingga pada proses persiapan penggunaannya lalu ditambah bahan kimia. Berdasarkan issu di masyarakat busung yang didatangkan dari Sulawesi diberi bahan pengawet berupa formalin. Namun setelah ditelusuri ke beberapa lokasi pengolahan, menurut pekerja saat ini bahan yang digunakannya adalah bahan kimia yang aman dan tidak membahayakan kesehatan yakni Hidrogen Peroksida $\left(\mathrm{H}_{2} \mathrm{O}_{2}\right)$ dan bahan-bahan pewarna tekstil yang belum diketahui dengan pasti jenis bahan kimia penyusunnya.

Disinilah seringkali ada salah pengertian mengenai pewarna (pemutih, merah, hijau) dan pengawet untuk bahan (janur ibung) yang seolah-olah aman digunakan selama tidak menyebabkan keracunan atau kematian (toksisitas akut), tetapi sebenarnya dapat menyebabkan kerusakan organ tubuh manusia, bila digunakan dalam jangka panjang (toksisitas kronik) dan pada kadar yang dapat membahayakan kesehatan.

Peneliti berasumsi bahwa para pengelola janur ibung belum memahami bahaya bahan kimia yang ditambahkannya pada janur ibung mengenai cara penggunaan dan cara melindungi diri dari bahaya bahan kimia dan masuknya bahan kimia ke dalam tubuh. Pemahaman mengenai bahan kimia yang ditambahkan pada janur ibung untuk menjamin keamanan bagi para pengguna janur ibung.

Penelitian ini bertujuan 1) mengidentifikasi jenis kegiatan pada pengolah janur ibung; 2) mengidentifikasi jenis dan kadar bahan kimia sebagai indikator keamanan bahan kimia yang ditambahkan pada proses pengolah janur ibung; 3) mengidentifikasi jenis alat pelindung diri yang digunakan pada pekerja pengolah janur ibung; 4) mengidentifikasi perubahan warna rambut pekerja pengolah janur Ibung; dan 5) menganalisis jenis kegiatan dengan perubahan warna rambut pada pekerja pengolah janur ibung. 


\section{Metode}

Penelitian ini dilaksanakan di wilayah Kecamatan Abiansemal Kabupaten Badung. Waktu penelitian dilaksanakan mulai bulan Juni sampai dengan bulan Oktober 2015. Sampel penelitian dalam penelitian ini adalah para pekerja pengolah janur Ibung sebanyak 18 orang. Adapun teknik pengambilan sampel pekerja pengolah janur ibung dilakukan dengan metode simple random sampling, Rumus yang digunakan untuk menghitung sample size pekerja adalah rumus sederhana untuk populasi infinit atau belum diketahui. ${ }^{1}$ Bahan kimia tambahan pada proses pengolahan janur ibung dianalisis sebagai data dukung dalam penggunaan alat pelindung diri (APD).

\section{Hasil dan Pembahasan}

Bahan Kimia pada Proses Pengolah Janur Ibung

Dari 10 parameter zat kimia yang dianalisis ditemukan hasil bahwa empat parameter menunjukkan hasil positif mengandung Rhodamin B, Merkuri (Hg), Besi (Fe), dan Amoniak. Rhodamin B berbahaya bagi kesehatan, dimana pada efek akut, paparan menyebabkan kerusakan parah pada mata, kulit menjadi iritasi diikuti dengan keluhan gatal terbakar dan menyengat pada kulit. Pada efek kronis, tampak sifat-sifat karsinogenik dan genotoksin. ${ }^{2}$ Dalam penelitian ini Rhodamin B terdapat pada pewarna merah janur ibung, dengan demikian janur ibung yang berwarna merah tidak dibolehkan bersentuhan dengan makanan yang dapat menyerap warna merah tersebut, karena bahan ini tidak bisa dimakan dan berbahaya bagi kesehatan.

Salah satu pengaruh merkuri $(\mathrm{Hg})$ terhadap fisiologi manusia yaitu; pada sistem saluran pencernaan dan ginjal, terutama akibat merkuri yang terakumulasi, juga berpengaruh terhadap sistem syaraf, karena senyawa kerusakan otak yang irreversible sehingga mengakibatkan kelumpuhan permanen serta berpengaruh terhadap pertumbuhan. ${ }^{3}$ Dalam penelitian ini merkuri ( $\mathrm{Hg})$ ditemukan pada pewarna merah janur ibung. Pekerja berkontak melalui pernapasan karena menghirup udara hasil proses perebusan dan pelarutan 
bahan kimia yang menguap ke udara, dan melalui kontak langsung dengan kulit karena bahan kimia dapat dipegang dengan sengaja atau tanpa sengaja pada saat proses mengolah janur ibung. Berdasarkan obsevasi pada pekerja pengolah janur ibung terlihat pula bahwa kulit tangan pekerja yang kontak langsung dengan bahan kimia menjadi iritasi, berwarna putih dan menebal.

Bahan kimia pemutih $\mathrm{H}_{2} \mathrm{O}_{2}$ 50\% ditambah garam dapur dan ada menambah-kan larutan pewangi yang dijual bebas tanpa label yang jelas. Hasil uji laboratorium pewangi mengandung kadar amoniak yang tinggi. Berdasarkan fungsi bahan kimia $\mathrm{H}_{2} \mathrm{O}_{2}$ di dalam sifatnya salah satunya adalah sebagai pewarna rambut dan termasuk pewarna rambut permanen, karena selain mengandung Hidrogen peroksida juga mengandung amoniak. Pewarna rambut permanen selain mengubah warna korteks rambut; juga mengubah warna pigmen dasar rambut, sehingga warna rambut tidak berubah walau dicuci berkali-kali. Senyawa peroksida $\left(\mathrm{H}_{2} \mathrm{O}_{2}\right)$ adalah termasuk zat aktif sebagai zat pemucat dan pemutih rambut, sediaan pemucat dan pemutih rambut ini juga digunakan untuk memucatkan, mencerahkan dan memutihkan rambut, sedangkan ammonia adalah termasuk zat penstabil. ${ }^{4,5}$

Besi $(\mathrm{Fe})$ dapat menyebabkan konjungtivitas, chroiditas, dan retinitis jika kontak dan tetap di jaringan. Inhalasi kronis konsentrasi yang berlebihan dari besi oksida asap atau debu dapat mengakibatkan pengembangan pneumoconiosis jinak, disebut siderosis, yang diamati sebagai perubahan $x$-ray. Hasil penelitian pewarna hijau bahan kimia pengolah janur ibung mengandung zar besi $(\mathrm{Fe})$ yang tinggi yaitu $7.189 \mathrm{mg} / \mathrm{l}$. Berdasarkan uraian di atas, bahan kimia tambahan zat pewarna pada janur ibung dapat dikatakan berbahaya bagi kesehatan pekerja dan tempat kerja yaitu udara, air dan tanah.

Efek samping dari zat pewarna yang ditambahkan pada janur ibung bagi kesehatan penggunanya adalah meliputi iritasi kulit, peradangan, reaksi alergi dan kemungkinan terjadi keracunan sistemik (gangguan pada 
hati dan ginjal, teratogenik, karsinogenik, dan sebagainya).

\section{Hasil observasi dan wawancara}

Pengelompokan identitas tenaga kerja pengolah janur ibung berdasarkan identitasnya sangatlah bervariasi. Ditinjau dari jenis kelamin, pendidikan, lama bekerja, dan umur pekerja. Jenis kelamin laki dan perempuan yang bekerja di lokasi pengolah janur ibung, menandakan pekerjaan tersebut bisa dikerjakan oleh baik laki-laki maupun perempuan. Pendidikan dapat berpengaruh pada pemahaman seseorang tentang informasi bahaya lingkungan di tempat kerja. Lama bekerja dapat berpengaruh pada terpaparnya pekerja oleh bahan kimia di tempat kerja. ${ }^{4}$

\section{Jenis kegiatan}

Jenis kegiatan di lokasi penelitian terdiri dari tiga bagian yaitu pencelupan, pengikatan dan penjemuran. Pencelupan janur ibung diawali dengan proses pelarutan, perebusan bahan kimia dan dilanjutkan dengan pencelupan janur ibung, sehingga berubah warna menjadi merah dan atau hijau sesuai tujuan.
Proses kegiatan ini menghasilkan uap, asap dan debu. Pengikatan janur ibung, pada bagian ini janur ibung yang sudah siap untuk didistribusikan ke masyarakat dirapikan bagianbagiannya yang rusak kemudian diikat dan selanjutnya diangkut oleh pekerja ke tempat penyimpanan. Penjemuran janur ibung, pada bagian ini janur ibung yang telah dicelup selanjutnya di jemur. Pada proses kegiatan penjemuran ini pekerja berkontak dengan janur yang telah dicelup.

\section{Warna rambut}

Rambut merupakan anggota badan yang terletak di atas kepala. Rambut terdiri atas akar dan tangkai rambut. Akar rambut dialiri darah melalui syaraf. Oleh karena itu rambut sensitif terhadap lingkungan, cuaca atau zatzat kimia yang bersentuhan langsung dengan rambut. ${ }^{8}$ Warna rambut dipengaruhi oleh adanya pigmen yang mengatur warna rambut. Pigmen rambut alami dapat berubah dengan adanya pewarna sintetis yang ditambahkan ke dalam rambut baik sengaja maupun tidak sengaja. Ketidaksengajaan muncul dari 
lingkungan, seperti pada lingkungan kerja pengolah janur ibung. Hasil penelitian menunjukkan para pekerja pengolah janur ibung mengalami perubahan warna rambut menjadi coklat kekuningan; seperti nampak pada gambar berikut:

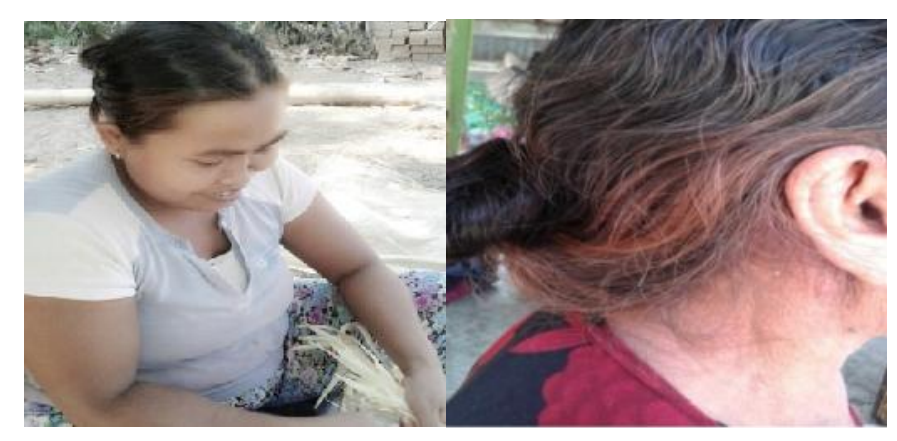

Gambar : Kenampakan ada perubahan warna rambut

\section{Alat pelindung diri (APD)}

Alat Pelindung Diri (APD) adalah alat yang digunakan untuk meminimalisasi tingkat paparan bahan berbahaya atau beracun serta menghindari kecelakaan akibat kerja di tempat kerja. $^{8}$ Jenis APD yang digunakan pada pengolah janur ibung di lokasi penelitian, meliputi: sarung tangan karet, sepatu boot, dan pakaian panjang (pada proses pencelupan), sedangkan pada proses perebusan dan pengikatan menggunakan masker, dan tutup kepala digunakan seadanya untuk menghindari sinar matahari. Adapun faktor lingkungan yang berpengaruh pada pekerja pengolah janur ibung adalah faktor lingkungan kimia. Faktor lingkungan kimia dalam penelitian ini berupa bahan baku kimia tambahan pewarna merah, pewarna hijau dan pemutih.

Berdasarkan hasil uji ChiSquare Test diperoleh hasil nilai $\left(\mathrm{X}^{2}\right)=$ 0,064 dengan Asymp Sig = 0,968 lebih besar dari $\alpha=5 \%(0,968>0,05)$, dan hipotesis alternatif tidak diterima, berarti tidak ada korelasi positif yang signifikan antara perubahan warna rambut pada pengolah janur ibung dan jenis kegiatannya. Dapat disimpulkan pula, bahwa semua pekerja dapat terkontak dengan bahan kimia tambahan zat pewarna dan mengalami 
perubahan warna rambut menjadi coklat kekuningan. Adapun beberapa hal yang dapat dilakukan pekerja untuk menghindari paparan bahan kimia dalam proses pengolah janur ibung yaitu menggunakan sarung tangan, masker, tutup kepala, pakaian kerja berlengan panjang, dan sepatu karet. Alat pelindung diri ini perlu disesuaikan juga dengan jenis kegiatannya. Seperti misalnya sarung tangan untuk proses pencelupan menggunakan sarung tangan karet yang lebih tebal dan sarung tangan berbahan kain dapat digunakan untuk proses pengikatan janur ibung. Masker digunakan pada semua kegiatan, tutup kepala pada semua kegiatan, dan sepatu pada proses pencelupan.

\section{Simpulan dan Saran}

Simpulan

Berdasarkan uraian di atas, dalam penelitian ini dapat disimpulkan bahwa terdapat tiga jenis kegiatan dalam pengolah janur ibung, ada tiga yaitu proses pencelupan, pengikatan dan penjemuran.

Jenis bahan kimia yang dianalisis berdasarkan pertimbangan timbulnya warna merah adalah Kadmium (Cd),
Timbal (Pb), Rhodamin B dan Merkuri (Hg). Pewarna hijau adalah Besi (Fe), Tembaga (Cu), Kobalt (Co), Kromium (Cr). Pewarna putih adalah Seng (Zn), dan pengawet adalah amoniak. Kadar bahan kimia yang terdeteksi oleh alat ukur pada limit deteksi 0,0001 mg / adalah Rhodamin B, Merkuri (Hg), Fe, dan Amoniak. $\mathrm{Cd}, \mathrm{Pb}, \mathrm{Cu}, \mathrm{Co}, \mathrm{Cr}$ dan Zn tidak terdeteksi oleh alat ukur pada limit deteksi 0,0001 mg/l. Bahan kimia pemutih untuk kadar $\mathrm{H}_{2} \mathrm{O}_{2} 50 \%$ tertulis pada label bahan dagang dalam kemasan 1 jerigen adalah 35 liter termasuk kedalam range 27,5 - 52\%, Oxidizer class-2, corrosive, berbahaya terhadap kesehatanya itu dapat membakar kulit/ jaringan,

Dalam proses penggunaannya $\mathrm{H}_{2} \mathrm{O}_{2}$ dicampur air dengan perbandingan 1:2 jadi konsentrasi akhir $\mathrm{H}_{2} \mathrm{O}_{2}$ yang dipakai adalah 16, $333 \%$. Konsentrasi 16,333 \% termasuk oxideser class -1 bahaya terbakar. Jenis alat pelindung diri di lokasi penelitian tidak digunakan secara merata oleh pekerja, karena hanya sebagaian pekerja saja yang menggunakan alat pelindung diri. 
Hasil analisis jenis kegiatan pengolahan janur ibung berkorelasi positif dengan perubahan warna rambut, berarti setiap pengolah janur ibung yang menangani langsung berisiko mengalami perubahan warna rambut.

\section{Saran}

Berdasarkan uraian di atas disarankan kepada pekerja pengolah janur ibung diharapkan menggunakan alat pelindung diri yang sesuai dengan tujuan keamanan dan keselamatan pekerja. Kepada pengelola disarankan hendaknya menyediakan APD (alat pelindung diri) yang dapat melindungi pekerja dari paparan bahan kimia tambahan zat pewarna. Kepada peneliti selanjutnya disarankan agar menganalisis zat kimia pencemar udara di lokasi pengolah janur ibung dan melakukan uji logam berat pada rambut pekerja.

\section{Daftar Pustaka}

1. Zainuddin, M. Metodelogi Penelitian, Surabaya: tp, 1999.

2. Mirayanti, Ni Komang. Tinjauan Kandungan Rhodamin-B Pada Kosmetika Jenis Pemerah Pipi yang Dijual di Pasar Asoka Kota Denpasar, Poltekkes Denpasar Jurusan Analis Kesehatan Denpasar. 2015.

3. Wurdiyanto. Bahaya Merkuri dalam Tubuh, http://barcabarcaindo.Blogspot.co.id/2015/04/ bahaya-merkuri-bagi-tubuh-ujimerkuri.html; 2007.

4. Pandu Wiranata IG, Aryasih IGA, Posmaningsih, DAA. Pengaruh Lama Kontak $\mathrm{H}_{2} \mathrm{O}_{2}$ terhadap Keluhan Subyektif Pengerajin Lontar di Kecamatan Mengwi Kab Badung Tahun 2013. Jurnal Kesehatan Lingkungan, Poltekkes Denpasar. Vol.4.No.1, Mei 2014. ISSN: 2014. 2089-5674.

5. Anomim. Mengenal Hidrogen Peroksida $\left(\mathrm{H}_{2} \mathrm{O}_{2}\right)$, http://www. forumsains.com / artikel/mengenalhidrogen-peroksida- $\mathrm{H}_{2} \mathrm{O}_{2} ; 2007$.

6. Sriana Aziz dan S.R, Muktiningsih, (1999). Studi Kegunaan Sediaan Rambut, Artikel, Media Litbangkes Volume IX Nomor I Tahun 1999, Puslitbang Farmasi, Badan Litbangkes, Jakarta.

7. Permenaker. Peraturan Menteri Tenaga Kerja dan Transmigrasi RI Nomor: $\quad$ Per.08/Men/VII/2010 tentang Alat Pelindung Diri, Jakarta: Menteri Tenaga Kerja dan Transmigrasi RI, 2010.

8. Fuadi, M. Hidrogen Peroksida untuk Bahan Pemutih Pulp, Universitas Gajah Mada, Yogyakarta, : http://ugm.ac.id/new //q=id/news/hidrogen-peroksidauntuk-bahan -pemutih-pulp, , 2009. 